\title{
Nitrogen Nutrition of New Guinea Impatiens 'Barbados' and Spathiphyllum 'Petite' in a Subirrigation System
}

\author{
Matthew W. Kent ${ }^{1}$ and David Wm. Reed ${ }^{2}$ \\ Department of Horticultural Sciences, Texas A\&M University, College Station, TX 77843-2133
}

\begin{abstract}
Additional index words. ebb and flow irrigation, flood and drain irrigation, Impatiens $\times$ hawkeri, peace lily, subsurface irrigation, water management, zero runoff
\end{abstract}

\begin{abstract}
Greenhouse cultural methods must minimize runoff to keep pace with environmental regulation aimed at protecting water resources. Two experiments were designed to investigate the effect of $N$ fertilization rate on New Guinea impatiens (Impatiens $\times$ hawkeri) and peace lily (Spathiphyllum Schott) in an ebb-and-flow subirrigation system. Maximum growth response for impatiens was centered around $8 \mathrm{~mm} \mathrm{~N}$ levels as measured by root and shoot fresh and dry weight, height, leaf number, leaf area, and chlorophyll concentration. For peace lily, growth peaked at about 10 mu N. Growing medium was divided into three equal layers: top, middle, and bottom. Root distribution favored the middle and bottom layers, and the relative distribution of roots was consistent as $\mathrm{N}$ level increased. EC remained low in middle and bottom layers at $\mathbf{N}$ concentrations below $10 \mathrm{~mm}$, but increased significantly for all layers at levels above $10 \mathrm{~mm}$. The EC for the top layer was 2 to 5 times higher than in the middle or bottom layers at all $\mathrm{N}$ levels. Increased nitrate concentration paralleled increased EC, while pH decreased as $\mathrm{N}$ concentration increased for impatiens and peace lily.
\end{abstract}

The rate of fertilizer application in greenhouse production is greater than in any other area of agriculture (Molitor, 1990). Traditional constant fertilization of containerized plant materials growing in porous media can generate an excessive level of runoff (Rathier and Frink, 1989). Local, state, and federal regulations intended to protect groundwater from agricultural runoff are necessitating more judicious application of fertilizers and control of runoff.

Ebb-and-flow (EF) subirrigation is already an accepted technique in European greenhouse production. Although EF was introduced in Europe as a labor- and water-saving measure (Molitor, 1990), the environmental goals of reducing water use, chemical runoff, and energy consumption translate into economic driving factors in the U.S. industry today (Raymond et al., 1986; Skimina, 1992). Before the inherent benefits of EF can be exploited, however, several cultural questions must be addressed. Salt accumulation in the growing medium is anticipated as one of EF's major drawbacks due to the absence of leaching; therefore, it is of paramount importance to determine the nutritional levels that allow for good crop nutrition under EF. Additionally, characterization of changes in subirrigation water during the recycling process will be important in establishing a working knowledge of EF.

Two experiments were designed to characterize some of the major parameters in $\mathrm{EF}$, including $\mathrm{N}$ application rates, salt accumulation in a standard peat-perlite medium, and changes that occur in the recycled irrigation solution using two ornamental species common in greenhouse culture, New Guinea impatiens and peace lily.

\section{Materials and Methods}

Experiment 1. New Guinea impatiens 'Barbados' (Impatiens $\times$ hawkeri) plugs (Paul Ecke Ranch, Encinitas, Calif.) were potted

Received for publication 16 Oct. 1995. Accepted for publication 29 Apr. 1996. We thank Paul Ecke Ranch and Twyford Plant Labs for providing the plant material. Use of trade names does not imply endorsement of products named or criticism of similar products not mentioned. The cost of publishing this paper was defrayed in part by the payment of page charges. Under postal regulations, this paper therefore must be hereby marked advertisement solely to indicate this fact.

${ }^{1}$ Senior research associate.

${ }^{2}$ Professor. into 10-cm-wide $\times 7$-cm-tall $(370-\mathrm{mL})$ azalea pots on 12 Dec. 1993. A total of 176 plants was used (22 plants/treatment). Soilless medium was the peat-perlite mix Sunshine no. 2 (Fison's Inc., Vancouver, B.C., Canada) with Micromax trace element mix (Grace-Sierra, Milpitas, Calif.) at the recommended rate of 1.059 $\mathrm{kg} \cdot \mathrm{m}^{-3}$. Sunshine mix no. 2 was chosen because it is adjusted for $\mathrm{pH}$ but contains no preplant nutrient charge. Newly transplanted plants were top watered with reverse osmosis (RO)-purified water until initial subirrigation (4 d). Experiments were conducted in a glasshouse with an average noontime light intensity of 609 $\mu \mathrm{mol} \cdot \mathrm{m}^{-2} \cdot \mathrm{s}^{-1}$ and average temperature of $26 / 17{ }^{\circ} \mathrm{C}$ day/night during the experimental period. Subirrigation began on $16 \mathrm{Dec}$. and was terminated on 3 Mar. 1994 (day 77). Eight $100 \times 110-\mathrm{cm}$ subirrigation trays (Midwest Growmaster, St. Charles, Ill.) were supplied with irrigation solution through a drain valve by a $1 / 200$ HP pump (Little Giant no. 1AA; Oklahoma City, Okla.) under manual control. Trays were arranged on two benches in groups of four. Tensiometers (model M; Irrometer Co., Riverside, Calif.) were placed into one pot (with plant) for each treatment. These plants were not considered for experimental results. In an initial calibration period of 1 week, plants were subirrigated when the surface of the medium began to dry, and tensiometer readings were noted. Subsequently, subirrigation was applied to individual treatments when tensiometer readings exceeded $25 \mathrm{kPa}$. Trays were flooded to a depth of $2 \mathrm{~cm}$. Trays required 2 to $3 \mathrm{~min}$ to fill and 2 to $3 \mathrm{~min}$ to drain and were held flooded for a maximum of $10 \mathrm{~min}$ at each watering, or until the tensiometer reading returned to $0 \mathrm{kPa}$ and the surface of the medium rewetted.

Irrigation solutions were $\mathrm{pH} 6.3$ and designed to give a final concentration of $1.5 \mathrm{~mm} \mathrm{P}$ and $2.0 \mathrm{~mm} \mathrm{~K}$, with one of the following concentrations of N: $0,2,4,8,10,15,20$, or $30 \mathrm{~mm}$. Solutions consisted of $0.39 \mathrm{~mm} \mathrm{~K}_{2} \mathrm{HPO}_{4}, 1.10 \mathrm{~mm} \mathrm{KH}_{2} \mathrm{PO}_{4}, 0.05 \mathrm{~mm} \mathrm{~K}_{2} \mathrm{SO}_{4}$, and $0,1,2,4,5,7.5,10$, or $15 \mathrm{~mm} \mathrm{NH}_{4} \mathrm{NO}_{3}$ in RO-purified water. Samples of individual subirrigation solutions were taken at each watering for analysis of $\mathrm{pH}, \mathrm{EC}, \mathrm{NH}_{4}$, and $\mathrm{NO}_{3}$. When the liquid level in the reservoirs was too low to be pumped, the solutions were replenished. Samples of the subirrigation solutions were analyzed within $1 \mathrm{~d}(\mathrm{pH}, \mathrm{EC})$ or held at $-20{ }^{\circ} \mathrm{C}\left(\mathrm{NH}_{4}, \mathrm{NO}_{3}\right)$. EC was measured with either a model 44600 conductivity/TDS meter 
(Hach Co., Loveland, Colo.) or a model 32 conductance meter with a 3400 series cell (YSI Co., Yellow Springs, Ohio). A model 701A pH meter (Orion Research, Cambridge, Mass.) with an M708 electrode (Markson Science, Phoenix, Ariz.), a model 9512 ammonia specific electrode (Orion Research Inc.), or a model 940900 nitrate specific electrode with a model 930700 reference electrode (Orion Research) were used to measure $\mathrm{pH}, \mathrm{NH}_{4}$ or $\mathrm{NO}_{3}$. For $\mathrm{NH}_{4}$ and $\mathrm{NO}_{3}$ determination, standard curves were constructed for each sample run.

Plant height and leaf number were measured at about 3-week intervals until day 49. Additionally, chlorophyll measurements were taken using a SPAD-501 chlorophyll meter (Minolta Camera Co., LTD, Japan) on day 40 using the five youngest fully expanded leaves on each plant. Eight representative plants were harvested for root and shoot fresh and dry weights on day 0 , and this was repeated using five plants/treatment on days 49,63 , and 77 . On day 77 , one $0.65-\mathrm{cm}$ disc from each of the five youngest fully expanded leaves of five plants was used for $N, N$-dimethylformamide (DMF) extraction of chlorophyll (Moran, 1982; Moran and Porath, 1980). The root zones of the same plants were divided into three equal (about 2-cm) horizontal zones (top, middle, and bottom) with a sharp knife. Discs were pulverized by hand and medium samples from the zones were collected for $\mathrm{pH}$ and $\mathrm{EC}$ analysis. Roots from each zone were harvested for fresh and dry weight by washing the remaining medium from the root masses on screens under running

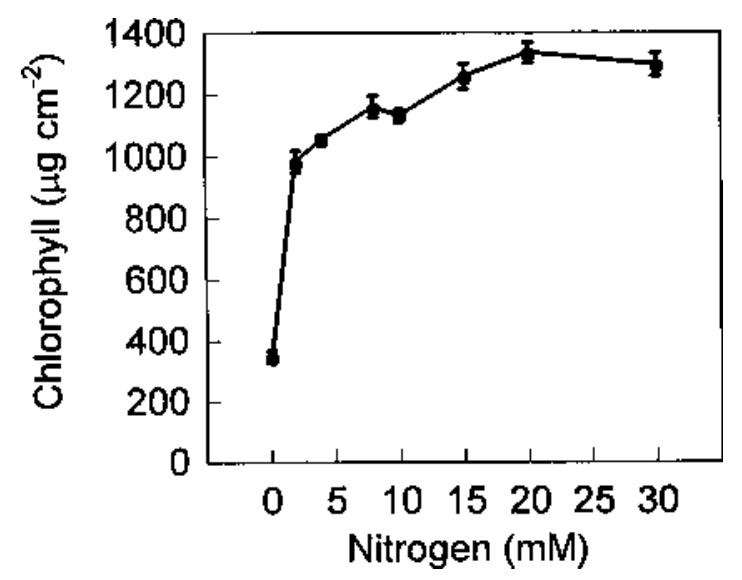

Fig. 1. Leaf chlorophyll concentrations of impatiens at final harvest (day 77). Bars represent standard error of the mean.

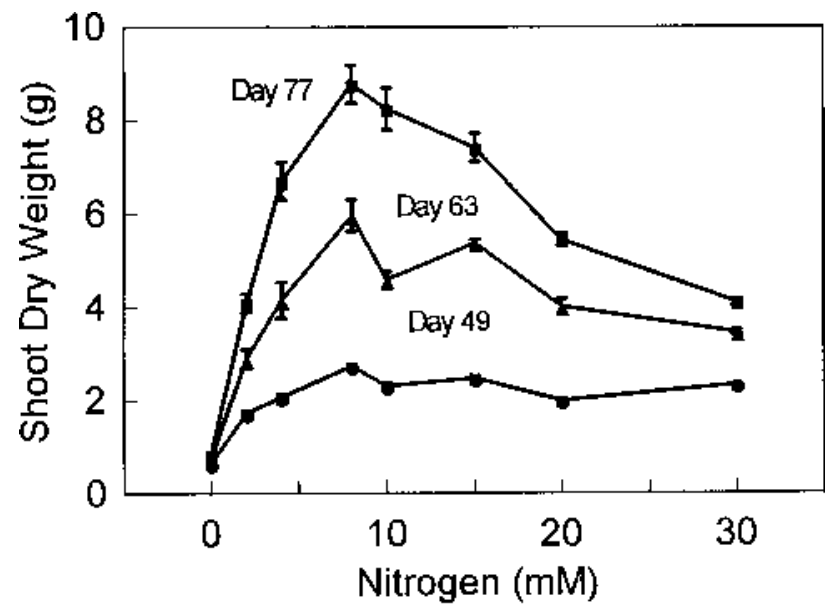

Fig. 2. Shoot dry weight of impatiens at day 49,63, and 77 harvests. Bars represent standard error of the mean. water. Soil analysis was done using a modification of the 1:2 extraction method of Warncke and Krauskopf (1983), extracting for $24 \mathrm{~h}$.

Experiment 2. New Guinea impatiens 'Barbados' plugs (Paul Ecke Ranch, Encinitas, Calif.) and peace lily 'Petite' (Spathiphyllum Schott) plugs (Twyford Plant Labs, Santa Paula, Calif.) were potted into $11-\mathrm{cm}$-wide $\times 9$-cm-tall $(615-\mathrm{mL})$ azalea pots on 2 Mar. 1994 and top-watered with RO water. A total of 80 plants of each species was used (10 plants/treatment). Subirrigation was done as in Expt. 1, and treatment solutions were applied beginning on 3 Mar. Impatiens were grown until 20 May (day 77), while peace lilies were grown until 7 June (day 96). During Expt. 2, plants were grown in a $50 \%$ shaded glasshouse, with average noontime light intensity of $565 \mu \mathrm{mol} \cdot \mathrm{m}^{-2} \cdot \mathrm{s}^{-1}$ and average temperature of $29.9 / 19^{\circ} \mathrm{C}$ day/night. Impatiens plant height was measured on days 0,28 , and 42 . On day 0 , five representative plants (both species) were harvested for shoot fresh and dry weight and for leaf area. Impatiens (five plants per treatment) were harvested for shoot weights and leaf area on days 42 and 77. Leaf area was measured using a model AM82 leaf area meter (Delta-T Devices LTD, Cambridge, U.K.) after drying leaves flat. In this way, weight measurements were performed on harvest day and leaf area measurement could be done at a later time. For New Guinea impatiens 'Barbados', dry leaf area was $86 \% \pm 1.0 \%$ of fresh leaf area. The growing medium was divided into top, middle, and bottom zones and sampled as in Expt. 1 for analysis of $\mathrm{pH}, \mathrm{EC}, \mathrm{NH}_{4}$, and $\mathrm{NO}_{3}$. Roots from zones were discarded. Due to slow growth, peace lily (five plants per treatment) was harvested for shoot and root fresh and dry weights on days 0 and 96 only. Methods were as previously described and all determinations were done on the same day as extraction.

\section{Results and Discussion}

Impatiens. Chlorophyll concentration in impatiens at final harvest (day 77) showed a characteristic response to increasing $\mathrm{N}$ levels (Fig. 1). Concentrations increased rapidly between 0 and 2 $\mathrm{mm} \mathrm{N}$, and thereafter increased gradually up to the $20 \mathrm{~mm} \mathrm{~N}$ treatment. This demonstrates limiting $\mathrm{N}$ concentration at $2 \mathrm{~mm}$ and below. Similar responses were demonstrated with spathiphyllum and dieffenbachia (Campos 1990; Campos and Reed 1993). Since chlorophyll concentration was expressed on a leaf area basis, the gradual increase above $2 \mathrm{~mm}$ may be due to the observed decrease in leaf area at $\mathrm{N}$ concentrations $>8 \mathrm{~mm}$ (data not shown). Results of chlorophyll measurement at experiment midpoint (day 40) using a chlorophyll meter were similar to data obtained by DMF extraction at final harvest (day 77).

Impatiens shoot dry weight did not vary between 2 and $30 \mathrm{~mm}$ $\mathrm{N}$ at day 49 (Fig. 2). Maximum dry weight was centered around 8 mм $\mathrm{N}$ for days 63 and 77. Shoot dry weight increased sharply up to $8 \mathrm{~mm} \mathrm{~N}$. Above $8 \mathrm{~mm} \mathrm{~N}$, dry weight values on day 77 decreased and were reduced by almost $50 \%$ at $30 \mathrm{~mm}$ N. Response to $\mathrm{N}$ fertilization levels as measured by shoot fresh weight, root fresh and dry weight, height, leaf number, and leaf area followed these same trends (data not shown). Evaluation of the overall quality of plant material at final harvest indicates an optimal $\mathrm{N}$ concentration of 8 to $10 \mathrm{~mm}$ (Fig. 3). Impatiens grown at $<4$ or $>15 \mathrm{~mm} \mathrm{~N}$ showed greatly diminished growth and low quality due to chlorosis or stunting, respectively.

The final size of impatiens was greatest at $8 \mathrm{~mm} \mathrm{~N}$ (Fig. 3). However, the relative growth rate (RGR) and net assimilation rate (NAR) increased up to about $4 \mathrm{~mm} \mathrm{~N}$, then remained relatively constant up to the highest $\mathrm{N}$ level tested of $30 \mathrm{~mm} \mathrm{~N}$ (Fig. 4). This 


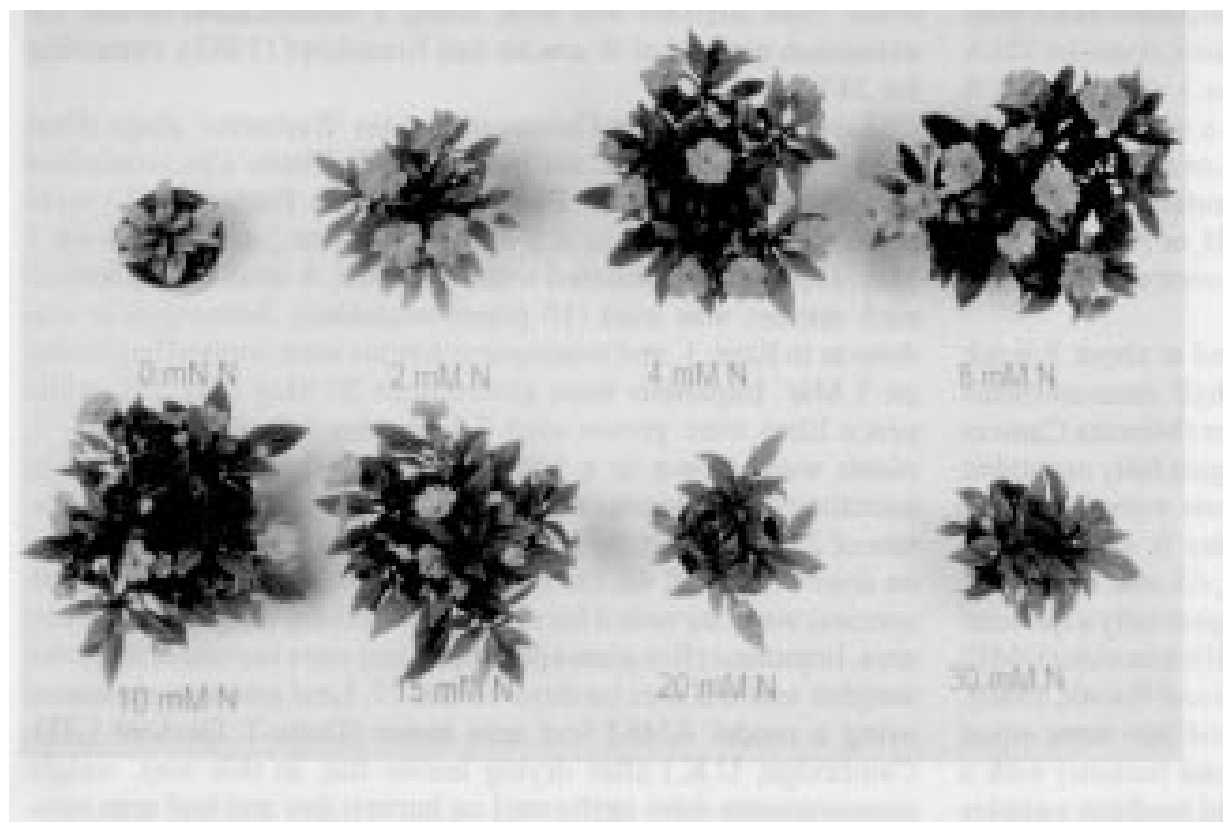

EC was significantly higher in the top layer than in the middle and bottom layers for all $\mathrm{N}$ concentrations (Fig. 6). Judd and Cox (1992) identified a growing medium EC of $1.5 \mathrm{dS} \cdot \mathrm{m}^{-1}$ as the upper limit to avoid growth suppression in New Guinea impatiens. However, their growing medium samples contained a combination of all growing medium layers. For greenhouse crops in general, Warncke and Krauskopf (1983) recommended an EC of 0.75 to 1.25 $\mathrm{dS} \cdot \mathrm{m}^{-1}$. Loss of vigor may occur when EC exceeds $1.25 \mathrm{dS} \cdot \mathrm{m}^{-1}$ for most established plants. The top layer equaled or exceeded 1.25 $\mathrm{dS} \cdot \mathrm{m}^{-1}$ at all $\mathrm{N}$ concentrations tested. The middle and bottom layer were about $1.25 \mathrm{dS} \cdot \mathrm{m}^{-1}$ or greater at concentrations $>10 \mathrm{~mm}$ N. Optimum growth was identified to be 8 to $10 \mathrm{~mm} \mathrm{~N}$. This indicates that the EC in the top layer was not a factor in plant growth at any $\mathrm{N}$ concentration, and as long as the EC of the middle and bottom layers could be maintained below $1.25 \mathrm{dS} \cdot \mathrm{m}^{-1}$, satisfactory plant growth could be expected.

Fig. 3. Impatiens plants at final harvest (day 77) after subirrigation treatments.

indicates that the photosynthetic apparatus and efficiency of drymatter production per unit leaf area were not significantly affected by the high $\mathrm{N}$ treatments, even though there was a significant salinity stress on the plants. With impatiens, total leaf number was not affected by $\mathrm{N}$ concentration, but total leaf area decreased as $\mathrm{N}$ concentration increased, due to smaller leaves (data not shown). Bethke and Drew (1992) demonstrated that extremely high salinity stress is required to damage the photosynthetic apparatus, and that salinity damage at moderate to high levels is due to other factors. The fact that NAR (Fig. 4) was maintained at a high level at high $\mathrm{N}$ concentrations indicated that the photosynthetic efficiency of the leaves was maintained.

The root systems were concentrated in the middle and bottom layers of the growing medium for all treatment levels between 0 and $30 \mathrm{~mm} \mathrm{~N}$ (Fig. 5). Maximum root growth was at 2 to $10 \mathrm{~mm} \mathrm{~N}$ for the bottom and middle layers. The top layer contained significantly less root mass for all treatment levels, with the greatest root dry weight at 2 to $8 \mathrm{~mm}$ N. Root dry weight decreased in all layers at concentrations $>8 \mathrm{~mm}$.

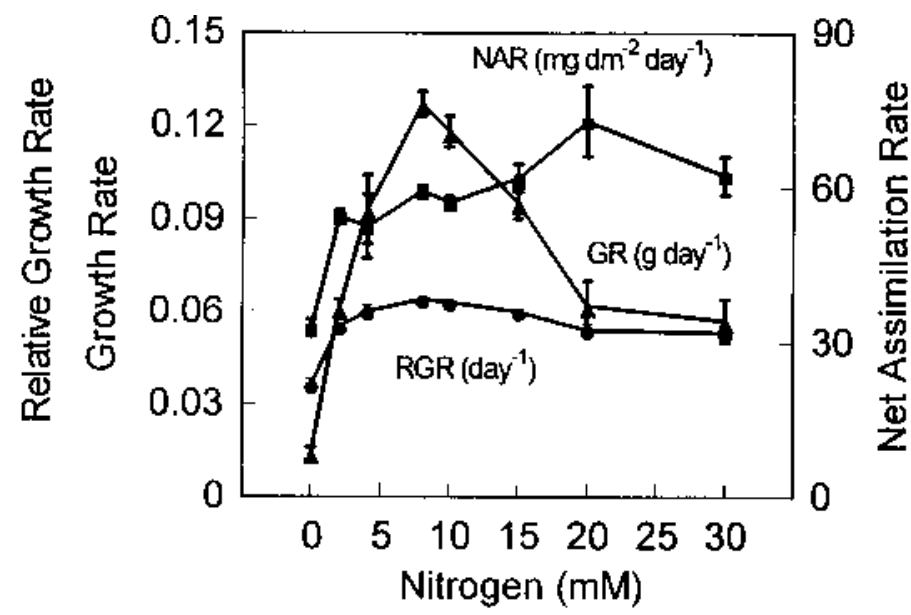

Fig. 4. Growth rate (GR), relative growth rate (RGR), and net assimilation rate (NAR) of impatiens over the course of the experiment (77 days). Bars represent standard error of the mean.

Quantification of nitrate concentration in root medium extractions yielded a profile of nitrate reflective of soluble salts levels (data not shown). Similar results were obtained by Yelanich and Biernbaum (1993) for medium nitrate as a component of total soluble salt. Nitrate in the top layer extract remained undetectable at applied $\mathrm{N}$ concentrations $<8 \mathrm{~mm}$, while at $30 \mathrm{~mm}$, nitrate was $>90$ $\mathrm{mm}$ (data not shown). Ammonium was also measured in growing medium extractions. While concentrations were greater at higher applied $\mathrm{N}$ concentrations and particularly in the top layer, reaching as high as $2.25,0.98$, and $0.57 \mathrm{~mm}$ at $30 \mathrm{~mm}$ applied $\mathrm{N}$ for the top, middle, and bottom respectively, all other $\mathrm{NH}_{4}$ concentrations were $<0.5 \mathrm{~mm}$.

Final root medium $\mathrm{pH}$ decreased with increasing $\mathrm{N}$ concentration for the middle and bottom layers, with values ranging from 7.0 in the $0 \mathrm{~mm} \mathrm{~N}$ treatments to as low as 5.0 in the $30 \mathrm{~mm} \mathrm{~N}$ treatment (data not shown). Subirrigation may enhance the stratification of $\mathrm{pH}$ values due to the absence of leaching of hydrogen ions associated with overhead irrigation or the nitrification of ammonium to nitrate. The nutrient solution used was 1 ammonium : 1 nitrate, but nitrate was shown to accumulate in the medium, possibly indicating nitrification. The use of nitrate- $\mathrm{N}$ sources may

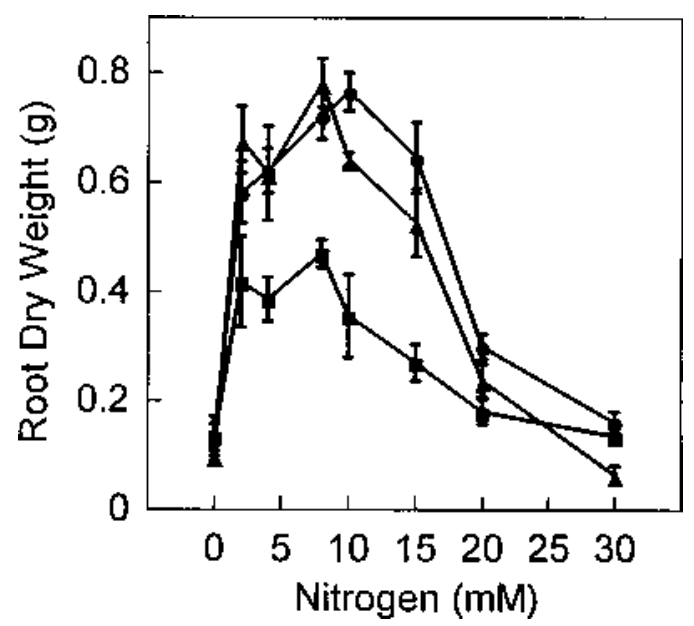

Fig. 5. Dry weight of impatiens roots recovered from the top ( $\square$ ), middle ( $)$, and bottom $(\boldsymbol{\Delta})$ zones of growing medium. Bars represent standard error of the mean. 


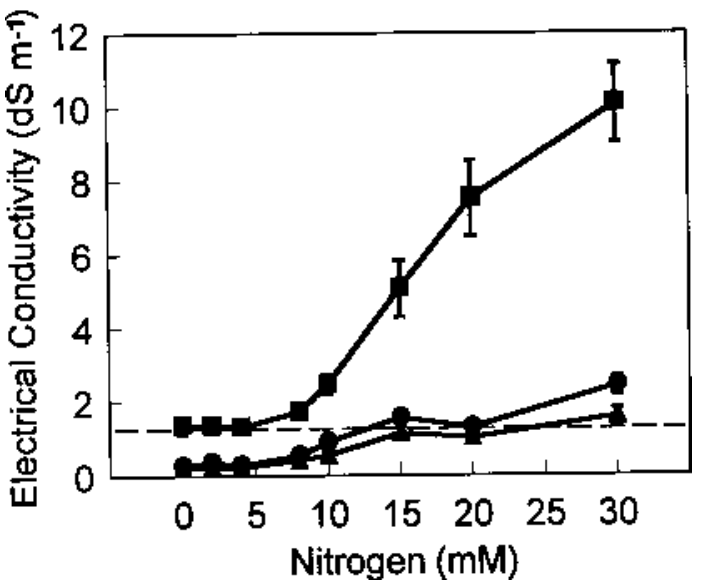

Fig. 6. Electrical conductivity of extracts (1:2 soil extraction method) from growing medium located in the top $(\boldsymbol{\square})$, middle $(\boldsymbol{O})$, and bottom $(\boldsymbol{\Delta})$ zones of the container. Dashed line at $1.25 \mathrm{dS} \cdot \mathrm{m}^{-1}$ represents upper limit of EC recommended by Warncke and Krauskopf (1983). Bars represent standard error of the mean.

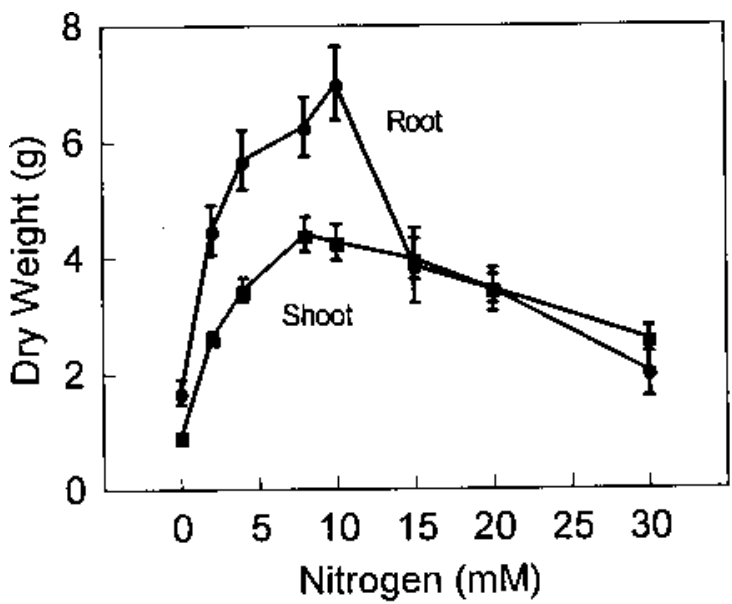

Fig. 7. Spathiphyllum root and shoot dry weight at final harvest (day 96). Bars represent standard error of the mean.

be justified to avoid root medium acidification (Molitor, 1990). This is especially compelling since the bulk of root growth was found to be in the middle and bottom layers.

Peace lily. Peace lily shoot and root dry weight showed a trend similar to impatiens growth patterns with respect to $\mathrm{N}$ fertilization rates (Fig. 7). The optimum $\mathrm{N}$ rate was about 8 to $10 \mathrm{~mm}$ N. Root growth declined dramatically above $10 \mathrm{~mm} \mathrm{~N}$, while shoot growth declined more gradually beyond $10 \mathrm{~mm} \mathrm{~N}$. The response of height, fresh weight and leaf area to $\mathrm{N}$ concentration followed the same trends as shoot and root dry weights. Measurements of EC, $\mathrm{NH}_{4}$, and $\mathrm{NO}_{3}$ mirrored the responses observed with impatiens.

It appears that the optimum $\mathrm{N}$ fertilization rate for impatiens and peace lily used in these experiments was 8 to $10 \mathrm{~mm}$. This represents the lower end of the optimum $\mathrm{N}$ application range of 7.5 to $30 \mathrm{~mm}$ determined for fertigation of peace lily by top watering with minimal leaching (Campos and Reed 1993). Reduced optimum $\mathrm{N}$ application rates under subirrigation have been reported for several species, including poinsettia (Dole et al., 1994) and Hedera helix (Holcomb et al., 1992).

Nitrate-N appeared to accumulate in the medium as a constant percentage of EC. Yelanich and Biernbaum (1994) showed similar trends in the root medium of top-watered poinsettias, as did Argo and Biernbaum (1995) for subirrigated poinsettias. Indeed, the accumulation of salts preferentially in the top layer of medium is not strictly a subirrigation phenomenon, but is also the case for topwatering (Argo and Biernbaum, 1995) and trickle irrigation (Molitor, 1990). There appears to be no subirrigation-specific salt accumulation threat to normal plant growth as long as quality irrigation water and reduced fertilizer levels are used. However, the magnitude of accumulation in the top zone of the medium in a subirrigation system may be very dramatic (Fig. 6).

Levels of $\mathrm{pH}$ in irrigation solutions decreased over time for some treatments, but no consistent trends were found, and the changes were limited to about $1 \mathrm{pH}$ unit. It is possible that contamination with microorganisms in the irrigation solutions (Molitor, 1990) may be responsible for these changes. However, the magnitude of $\mathrm{pH}$ change in this case should not be a factor affecting normal plant growth.

The EC and nitrate concentration of irrigation solutions remained constant (data not shown) and the solutions remained clear in the stock tanks over time for all treatment levels and both species. This indicates that the fertilizer solution entered the growing medium pore space by mass flow and minimal drainage from the medium occurred. Therefore, the nutrient solution did not concentrate over time due to evaporation nor did the balance of nutrients change due to selective absorption.

\section{Literature Cited}

Argo, W.R. and J.A. Biernbaum. 1995. The effect of irrigation method, water-soluble fertilization, preplant nutrient charge, and surface evaporation on early vegetative and root growth of poinsettia. J. Amer. Soc. Hort. Sci. 120:163-169.

Bethke, P. and M.C. Drew. 1992. Stomatal and non-stomatal components of inhibition of photosynthesis in leaves of Capsicum annuum during progressive exposure to $\mathrm{NaCl}$ salinity. Plant Physiol. 99:219-226.

Campos, R. 1990. The influence of irrigation water salinity on optimal nitrogen, phosphorus, and potassium liquid fertilizer rates. MS thesis. Texas A\&M Univ.

Campos, R. and D.W. Reed. 1993. Determination of constant-feed liquid fertilization rates for Spathiphyllum 'Petite' and Dieffenbachia 'Camille' J. Environ. Hort. 11:22-24.

Dole, J.M., J.C. Cole, and S.L. von Broembsen. 1994. Growth of poinsettias, nutrient leaching, and water-use efficiency respond to irrigation methods. HortScience 29:858-864.

Holcomb, E.J., S. Gamez, D. Beattie, and G.C. Elliott. 1992. Efficiency of fertigation programs for baltic ivy and asiatic lily. HortTechnology 2:43-46.

Judd,L.K. andD.A.Cox. 1992. Growth of new guineaimpatiensinhibited by high growth medium electrical conductivity. HortScience 27:1193-1194.

Molitor, H.-D. 1990. Bedding and pot plants: The European perspective with emphasis on subirrigation and recirculation of water and nutrients. Acta. Hort. 272:165-171.

Moran, R. 1982. Formulae for determination of chlorophyllous pigments extracted with $N, N$-dimethylformamide. Plant Physiol. 69:1376-1381.

Moran, R. and D. Porath. 1980. Chlorophyll determination in intact tissue using $N, N$-dimethylformamide. Plant Physiol. 65:478-479.

Rathier, T.M. and C.R. Frink. 1989. Nitrate in runoff water from container grown juniper and alberta spruce under different irrigation and fertilization regimes. J. Environ. Hort. 7:32-35.

Raymond, F.H., R.H. Sciaroni, and R.L. Branson. 1986. Water conservation and recycling in ornamentals production. HortScience 21:35-38.

Skimina, C.A. 1992. Recycling water, nutrients, and waste in the nursery industry. HortScience 27:968-971.

Warncke, D.D. and D.M. Krauskopf. 1983. Greenhouse growth media: Testing \& nutrition guidelines. Michigan State Univ. Coop. Ext. Ser. Bul. E-1736.

Yelanich, M.V. and J.A. Biernbaum. 1994. Fertilizer concentration and leaching affect nitrate-nitrogen leaching from potted poinsettia. HortScience 29:874-875.

Yelanich, M.V. and J.A. Biernbaum. 1993. Root-medium nutrient concentration and growth of poinsettia at three fertilizer concentrations and four leaching fractions. J. Amer. Soc. Hort. Sci. 118:771-776. 